\title{
NADGIŚNIENIE TETINICZE
}

Redaktor działu: prof. dr hab. n. med. Krzysztof Narkiewicz

\section{Spuścizna badania ASCOT — obserwacja odległa ASCOT-Legacy}

ASCOT trial heritage - ASCOT-Legacy long-term follow-up observation

\section{Anna Szyndler}

Klinika Nadciśnienia Tętniczego i Diabetologii Gdańskiego Uniwersytetu Medycznego

\section{STRESZCZENIE}

Badanie ASCOT było przełomowym badaniem, w którym połączenie nowych leków hipotensyjnych skuteczniej niż terapia lekami starszej generacji chroniło pacjentów przed występowaniem powikłań sercowo-naczyniowych. Wyniki dużych badań klinicznych, choć zmieniają codzienną praktykę lekarską, jednak nie przynoszą jednoznacznych danych dotyczących odległych korzyści ze stosowania określonych schematów postepowania. Takie zagadnienie podjęto w badaniu ASCOT-Legacy, w którym autorzy zadali sobie pytanie, czy wybór schematu terapeutycznego na początkowym etapie leczenia ma znaczenie dla rokowania odległego oraz czy w wieloletniej obserwacji utrzyma się przewaga korzystnego działania schematu amlodypina/peryndopryl w postaci zmniejszenia śmiertelności wśród pacjentów. Analiza śmiertelności pacjentów uczestniczących w pierwotnym badaniu ASCOT po średnio 16 latach obserwacji wykazała 29-procentową redukcję liczby zgonów z powodu udarów w grupie leczonej nowymi lekami hipotensyjnymi, natomiast wśród pacjentów niezakwalifikowanych do ramienia LLA - zmniejszenie liczby zgonów z przy- czyn sercowo-naczyniowych o $21 \%$ oraz obniżenie - 24\% śmiertelności z powodu choroby wieńcowej.

Choroby Serca i Naczyń 2019, 16 (2), 112-115

Słowa kluczowe: badanie ASCOT, terapia złożona, śmiertelność sercowo-naczyniowa

\section{ABSTRACT}

The ASCOT trial was a breakthrough observation where the newer hypotensive drugs proved superior to the older generation drugs in reducing cardiovascular complications. Large clinical trials results, despite their influence on everyday practice, do not answer the question on long term benefits of a certain therapeutic approach. This question was raised in ASOCT-Legacy trial where the authors searched the answer if the initially started therapy influences the long term prognosis and if discovered amlodipine/ /perindopril combination advantage will persist for the long time and result in reducing patients' mortality. The mortality analysis in ASCOT-Legacy trial patients, after on average of 16 years of observation, indicated to $29 \%$ reduction in number of stroke deaths in newer 
drugs group. At the same time the patients not included in the LLA arm benefited with $21 \%$ reduction in cardiovascular deaths and $24 \%$ reduction in coronary disease mortality.
Choroby Serca i Naczyń 2019, 16 (2), 112-115

Key words: ASCOT trial, combination therapy, cardio-vascular mortality
W wytycznych Europejskiego Towarzystwa Nadciśnienia Tętniczego (ESH, European Society of Hypertension)/Europejskiego Towarzystwa Kardiologicznego (ESC, European Society of Cardiology) z 2018 roku dotyczących postępowania w nadciśnieniu tętniczym [1] podkreśla się konieczność poprawy skuteczności leczenia nie tylko krótkoterminowo, lecz również w obserwacji odległej, a co za tym idzie - długotrwałego obniżenia ryzyka śmiertelności i chorobowości sercowo-naczyniowej. Temu celowi mają służyć opracowane nowe schematy rozpoczynania i intensyfikacji terapii hipotensyjnej, w których podkreśla się konieczność stosowania leczenia złożonego o udowodnionej skuteczności od momentu rozpoczynania leczenia.

Publikowane wytyczne z reguły są oparte na badaniach klinicznych o czasie obserwacji nie dłuższym niż 5 lat. Dane z dłuższych obserwacji, w ramach których jest porównywana skuteczność dwóch aktywnych ramion badania, są bardzo ograniczone [2]. Dlatego też wnioski na temat odległych korzyści ze stosowania poszczególnych schematów terapeutycznych wynikają w większym stopniu z założeń o przedłużonych korzyściach niż $z$ dowodów na ich istnienie.

Jednym $\mathrm{z}$ badań o przedłużonej obserwacji, poza okres aktywnego leczenia, jest badanie ASCOT (Anglo-Scandinavian Cardiac Outcomes Trial)-Legacy [3] stanowiące kontynuację badania ASCOT [4]. Badanie ASCOT zaplanowano w celu porównania dwóch schematów terapii hipotensyjnej (amlodypina $+w$ razie potrzeby peryndopryl $v$. atenolol $+\mathrm{w}$ razie potrzeby diuretyk tiazydowy) (ramię BPLA [Blood Pressure Lowering Arm]) oraz atorwastatyny z placebo wśród pacjentów ze stężeniem cholesterolu poniżej $250 \mathrm{mg} / \mathrm{dl}$ nieprzyjmujących $\mathrm{w}$ tamtym okresie statyny ani fibratu (ramię LLA [Lipid Lowering Arm]). Do badania ASCOT zakwalifikowano osoby obciążone zwiększonym ryzykiem sercowo-naczyniowym (> 3 czynniki ryzyka), w ramach prewencji pierwotnej. Część badania obejmującego ramie lipidowe (LLA) zakończono przedwcześnie w 2002 roku z powodu znacznie mniejszej częstości występowania zawałów serca i zgonów z powodu choroby wieńcowej $\mathrm{w}$ grupie leczonej atorwastatyną. W badaniu ASCOT [4], zakończonym ostatecznie w 2005 roku, wykazano mniejszą liczbę udarów mózgu, zdarzeń i procedur sercowo-naczyniowych oraz zgonów z dowolnej przyczyny, a także rzadszy rozwój cukrzycy de novo w grupie osób leczonych zgodnie ze schematem opartym na amlodypinie w porównaniu z grupą przyjmującą atenolol, mimo nieistotnej różnicy w zakresie wartości ciśnienia tętniczego uzyskanej między grupami badanymi. Postulowanymi mechanizmami odpowiedzialnymi za większą skuteczność schematu amlodypina \pm peryndopryl jest znaczniejsze obniżenie ciśnienia centralnego [5] oraz zmniejszenie zmienności ciśnienia tętniczego $\mathrm{w}$ tej grupie pacjentów [6, 7].

Spadkobiercą badania ASCOT jest badanie ASCOT-Legacy, w którym obserwowano wszystkich pacjentów uczestniczących w badaniu ASCOT na terenie Wielkiej Brytanii, około 16 lat od rozpoczęcia badania, średnio 10 lat od zakończenia aktywnej jego fazy. W 2015 roku na podstawie oficjalnego rejestru przyczyn zgonów oceniono przeżycie pacjentów pierwotnie obserwowanych w badaniu ASCOT (ryc. 1).

Autorzy obserwacji ASCOT-Legacy postawili sobie pytanie o to, czy wybór schematu terapeutycznego na początkowym etapie leczenia ma istotne znaczenie dla rokowania odległego oraz czy w wieloletniej obserwacji utrzyma się przewaga korzystnego działania schematu opartego na amlodypinie $w$ postaci zmniejszenia śmiertelności. Po zakończeniu obserwacji w ramieniu nadciśnieniowym w ciągu kolejnych 10 lat u pacjentów, którzy w głównym badaniu ASCOT byli poddani terapii skojarzonej amlodypiną \pm \pm peryndoprylem, zaobserwowano o 29\% mniej zgonów z powodu udaru. Co więcej, analiza śmiertelności pacjentów, którzy nie byli zakwalifikowani do grupy LLA (tj. obciążeni większą liczbą czynników ryzyka oraz obciążeni chorobami układu sercowo-naczyniowego), ujawniła 21-procentowe zmniejszenie liczby zgonów z przyczyn sercowo-naczy- 


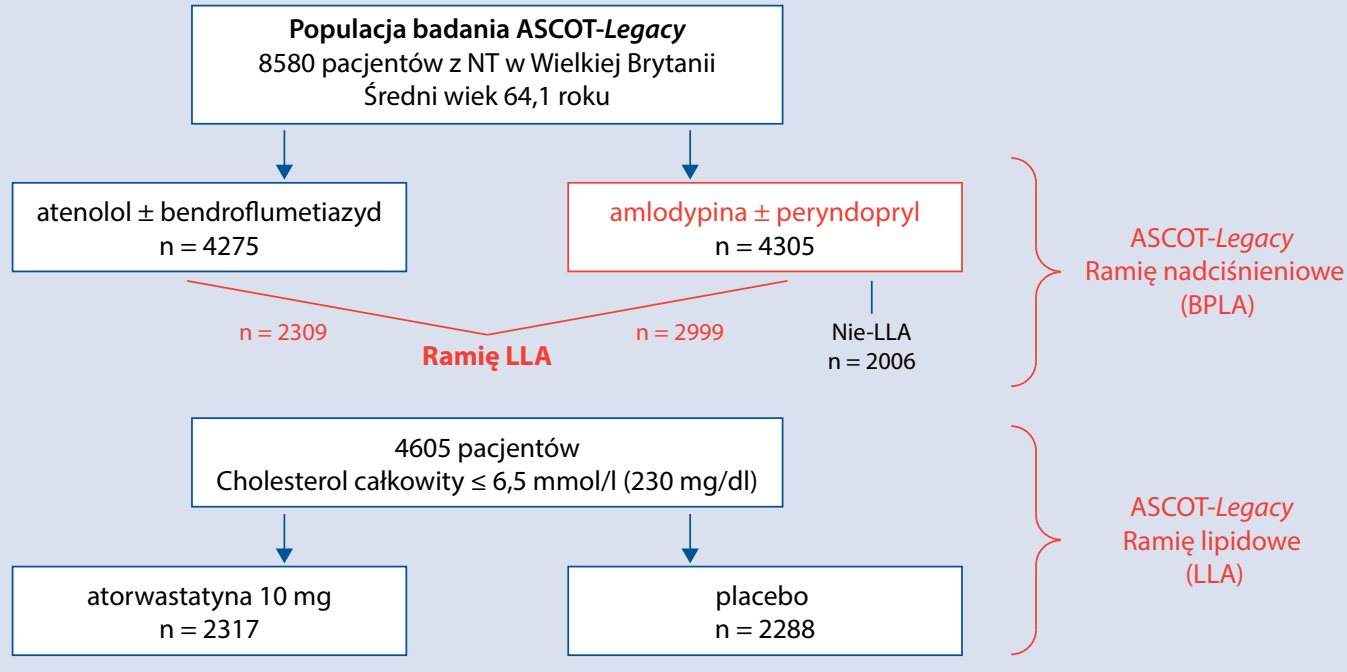

Rycina 1. Schemat badania ASCOT (Anglo-Scandinavian Cardiac Outcomes Trial)-Legacy (opracowano na podstawie [3]); NT — nadciśnienie tętnicze; LLA — Lipid Lowering Arm; BPLA — Blood Pressure Lowering Arm

niowych oraz zmniejszenie o $24 \%$ liczby zgonów z powodu choroby wieńcowej. Warto podkreślić, że niezależnie od przynależności pacjenta do ramienia LLA (przyjmujących i nieprzyjmujących statyny) u pacjentów leczonych amlodypiną 土 peryndoprylem częstość występowania zgonów była podobna, co może świadczyć o skuteczności schematu amlodypina \pm peryndopryl $\mathrm{w}$ zapobieganiu zgonom sercowo-naczyniowym niezależnie od wyjściowego ryzyka pacjentów.

Na podstawie przedstawionych analiz można stwierdzić, że stosowanie terapii hipotensyjnej opartej na amlodypinie w połączeniu z peryndoprylem w początkowym okresieleczenia wiązało się z mniejszą częstością zgonów z powodu udaru mózgu w czasie 16-letniej obserwacji. Co więcej, korzyści z tak zaplanowanej terapii w zakresie śmiertelności sercowo-naczyniowej i spowodowanej chorobą wieńcową były szczególnie widoczne $w$ grupie chorych obciążonych wyższym wyjściowym ryzykiem sercowo-naczyniowym
(non-LLA). Różnic utrzymujących się w obserwacji długoterminowej między badanymi schematami terapeutycznymi nie można przypisywać różnicy ciśnienia tętniczego w obu grupach osiągniętej w czasie aktywnej fazy badania i w obserwacji długoterminowej. W ASCOT-Legacy różnica ciśnienia tętniczego między obiema grupami wynosiła niewiele ponad $1 \mathrm{~mm}$ Hg i nie może być odpowiedzialna za utrzymującą się istotną różnicę śmiertelności z powodu udarów mózgu.

Wyniki przedłużonej, blisko 16-letniej, obserwacji pacjentów biorących udział w badaniu ASCOT wskazują na znaczenie wyboru początkowej terapii w leczeniu pacjentów z nadciśnieniem tętniczym. Niezależnie od postępowania po zakończeniu aktywnej fazy badania wśród pacjentów przyjmujących początkowo amlodypinę $\mathrm{w}$ połączeniu z peryndoprylem wykazano istotne korzyści kliniczne w porównaniu $z$ osobami poddanymi leczeniu według schematu opartego na beta-adrenolityku z diuretykiem tiazydo- wym, szczególnie w zakresie zapobiegania udarom mózgu.

Warto więc podkreślić znaczenie tej spuścizny (tj. ang. 'legacy') badań ASCOT i ASCOT-Legacy wskazującej, że nie bez znaczenia jest zarówno wybór pierwszego schematu terapeutycznego w celu odległego obniżenia ryzyka zgonu sercowo-naczyniowego u pacjenta, jaki wytrwałość $\mathrm{w}$ jego stosowaniu.

\section{KONFLIKT INTERESÓW}

Artykuł powstał we współpracy z firmą Servier Polska sp. z o.o.

\section{PIŚMIENNICTWO}

1. Williams B, Mancia G, Spiering W, et al. Authors/Task Force Members, ESC Scientific Document Group. 2018 ESC/ESH Guidelines for the management of arterial hypertension. Eur Heart J. 2018; 39(33): 3021-3104, doi: 10.1093/eurheartj/ehy339, indexed in Pubmed: 30165516.

2. Kostis WJ, Thijs L, Richart T, et al. Persistence of mortality reduction after the end of randomized therapy in clinical trials of blood pressure-lowering medications. Hypertension. 2010; 56(6): 1060-1068, doi: 10.1161/HYPERTENSIONAHA.110.160291, indexed in Pubmed: 20975031.

3. Gupta A, Mackay J, Whitehouse A, et al. Long-term mortality after blood pressure-lowering and lipid-lowering treatment in 
patients with hypertension in the Anglo-Scandinavian Cardiac Outcomes Trial (ASCOT) Legacy study: 16-year follow-up results of a randomised factorial trial. Lancet. 2018; 392(10153): 1127-1137, doi: 10.1016/S0140-6736(18)31776-8, indexed in Pubmed: 30158072.

4. Dahlöf B, Sever PS, Poulter NR, et al. ASCOT Investigators. Prevention of cardiovascular events with an antihypertensive regimen of amlodipine adding perindopril as required versus atenolol adding bendroflumethiazide as required, in the Anglo-Scandinavian Cardiac Outcomes Trial-Blood Pressure Lowering Arm (ASCOT-
-BPLA): a multicentre randomised controlled trial. Lancet. 2005; 366(9489) : 895-906, doi: 10.1016/S0140-6736(05)67185-1, indexed in Pubmed: 16154016.

5. Williams B, Lacy PS, Thom SM, et al. CAFE Investigators, Anglo-Scandinavian Cardiac Outcomes Trial Investigators, CAFE Steering Committee and Writing Committee. Differential impact of blood pressure-lowering drugs on central aortic pressure and clinical outcomes: principal results of the Conduit Artery Function Evaluation (CAFE) study. Circulation. 2006; 113(9): 1213-1225, doi: 10.1161/CIRCULATIONAHA. 105.595496, indexed in Pubmed: 16476843.
6. Rothwell PM, Howard SC, Dolan E, et al. ASCOT-BPLA and MRC Trial Investigators. Effects of beta blockers and calcium-channel blockers on within-individual variability in blood pressure and risk of stroke. Lancet Neurol. 2010; 9(5): 469-480, doi: 10.1016/S1474-4422(10)70066-1, indexed in Pubmed: 20227347

7. Rothwell PM, Howard SC, Dolan E, et al. Prognostic significance of visit-to-visit variability, maximum systolic blood pressure, and episodic hypertension. Lancet. 2010; 375(9718): 895-905, doi: 10.1016/S0140-6736(10)60308-X, indexed in Pubmed: 20226988. 